(c) American Dairy Science Association, 2005.

\title{
Fermentation $\mathrm{pH}$ and Temperature Influence the Cryotolerance of Lactobacillus acidophilus RD758
}

\author{
Y. Wang, ${ }^{1}$ G. Corrieu, ${ }^{1}$ and C. Béal ${ }^{2}$ \\ ${ }^{1}$ Institut National de la Recherche Agronomique and \\ ${ }^{2}$ Institut National Agronomique Paris-Grignon, \\ Génie et Microbiologie des Procédés Alimentaires, \\ 78850 Thiverval-Grignon, France
}

\begin{abstract}
The effects of 3 fermentation temperatures (30, 37, and $\left.42^{\circ} \mathrm{C}\right)$ and 3 fermentation $\mathrm{pH}(4.5,5$, and 6$)$ on the cryotolerance of Lactobacillus acidophilus RD758 were studied in relation to their fatty acid composition. Cryotolerance was defined as the ability of the cells to recover their acidification activity after freezing and frozen storage at $-20^{\circ} \mathrm{C}$. Better cryotolerance was obtained in cells grown at $30^{\circ} \mathrm{C}$ or at $\mathrm{pH} 5$; these cells showed no loss in acidification activity during freezing and a low rate of loss in acidification activity during frozen storage. On the other hand, cells grown at $42^{\circ} \mathrm{C}$ or at $\mathrm{pH} 4.5$ displayed poor cryotolerance. The membrane fatty acid composition was analyzed and related to the cryotolerance using principal component analysis. The improved cryotolerance observed during the freezing step was associated with a high ratio of unsaturated to saturated fatty acids, a low C18:0 content, and high C16:0 and cyclic C19:0 relative concentrations. High resistance during frozen storage was related to a high cycC19:0 concentration. Finally, the low cryotolerance observed after fermentation at $\mathrm{pH} 4.5$ was explained by a low C18:2 content.
\end{abstract}

(Key words: lactic acid bacteria, temperature, $\mathrm{pH}$, fatty acid composition)

Abbreviation key: $\mathbf{d t f}=$ difference between the acidification activities measured before and after freezing; $\mathbf{k}=$ rate of loss in acidification activity; $\mathbf{t c}=$ initial acidification activity before freezing; tpH5.5 = acidification activity (time necessary to reach $\mathrm{pH} 5.5$ ); ts = storage time; $\mathbf{U} / \mathbf{S}=$ ratio of unsaturated to saturated fatty acid concentrations.

\section{INTRODUCTION}

Lactic acid bacteria are important starters used in the food and pharmaceutical industries. Their preser-

Received June 8, 2004.

Accepted September 17, 2004.

Corresponding author: C. Béal; e-mail: beal@grignon.inra.fr. vation is generally obtained by freezing or freeze-drying (To and Etzel, 1997) to maintain the viability and main technological properties of the bacteria: acidification activity, aroma production, texture formation, and probiotic properties (Fonseca et al., 2003). However, some strains are sensitive to freezing and freeze-drying, both of which lower the performance of starter cultures (Foschino et al., 1996). This sensitivity is related to the deterioration of the cell physiological state, caused by various stresses appearing during starter production and preservation. Cold stress, which takes place during the cooling and freezing steps and during frozen storage, is the main cause of loss of bacterial activity. Other unfavorable conditions such as heat stress (Desmond et al., 2002), acid stress (De Angelis et al., 2001), starvation (Maus and Ingham, 2003), osmotic stress (Guerzoni et al., 2001), and oxidative stress (Aubert et al., 2002) affect the performance of starters.

Adaptive responses to stress in lactic acid bacteria vary with bacterial species and stress conditions, but 2 main responses are observed. The first one consists of the synthesis of some specific proteins, which have been observed under various stress conditions, especially cold or heat stress and acid stress. A set of 7-kDa proteins, named cold shock proteins (CspA-CspI), was strongly induced in response to a sudden drop of temperature, by Streptococcus thermophilus (Wouters et al., 1999) and Lactococcus lactis (Wouters et al., 2001). In Lc. lactis, the heat shock response was characterized by an enhanced synthesis of heat shock proteins, such as GroEL, DnaK, DnaJ, and GrpE (Broadbent et al., 1997). The drop in final culture $\mathrm{pH}$ to 4.5 results in synthesis of 9 proteins (14.1 to $56.2 \mathrm{kDa}$ ) in Lactobacillus acidophilus (Lorca and Font de Valdez, 2001) and of some heat shock proteins in Lc. lactis (Frees et al., 2003). Finally, an acid shock at pH 4.75 also induced expression of 3 heat shock proteins (GroES, GroEL, and DnaK) in Lactobacillus bulgaricus (Lim et al., 2000).

The second response is related to changes in membrane fatty acid composition. The cellular adaptive mechanism induced by cold shock consists of an increase in the unsaturated fatty acid content of mem- 
brane phospholipids, which leads to a decrease in the solid-to-fluid transition temperature and thus, to an increase in membrane fluidity. Consequently, the ratio between unsaturated and saturated fatty acids (U/S) is inversely correlated with the growth temperature, as shown by Lonvaud-Funel and Desens (1990) with Lactobacillus plantarum, and by Suutari and Laakso (1992) with Lactobacillus fermentum. Béal et al. (2001) showed that a decrease in the fermentation $\mathrm{pH}$ increased the U/S ratio of Strep. thermophilus and improved the recovery of its acidification activity.

In addition, some specific fatty acids play an important role in stress response. Fernandez Murga et al. (2000) observed an increase of C16:0 and C18:2 fatty acids in $L b$. acidophilus grown at low temperature $\left(25^{\circ} \mathrm{C}\right)$. The $\mathrm{C} 18: 1$ fatty acid concentration increased in response to low temperature in $L b$. plantarum (Russell et al., 1995), to acid pH in Strep. thermophilus (Béal et al., 2001), and to osmotic stress in Lc. lactis (Guillot et al., 2000). On the contrary, C18:1 concentration decreased in response to freezing in lactic streptococci (Gilliland and Speck, 1974), and to spray-drying in $L b$. acidophilus (Brennan et al., 1986). A high cycC19:0 concentration favored the cryotolerance of $L b$. bulgaricus, Lactobacillus helveticus, and Lb. acidophilus (Gomez Zavaglia et al., 2000). The cycC19:0 also increased in response to acid stress (Béal et al., 2001), osmotic stress (Guillot et al., 2000), ethanol stress (Teixeira et al., 2002), and high age of culture (Drici-Cachon et al., 1996).

Different methods are presently proposed to improve the quality of lactic and probiotic starters: the use of effective cryoprotectants (Fonseca et al., 2003), the use of adequate freezing and storage conditions (Foschino et al., 1996), and the selection of more-resistant strains (Monnet et al., 2003). In addition, the application of special environmental conditions during fermentation has been proposed by some authors (Gilliland and Rich, 1990; Fernandez Murga et al., 2000; Palmfeldt and Hahn Hagerdal, 2000; Béal et al., 2001). Therefore, this work aims to adapt $L b$. acidophilus, by applying different temperature and $\mathrm{pH}$ conditions during fermentation, to improve its resistance to freezing and frozen storage. The analysis of the membrane fatty acid composition of adapted cells should improve our understanding of the cellular adaptive response.

\section{MATERIALS AND METHODS}

\section{Bacterial Strain and Media}

Freeze-dried Lb. acidophilus RD758 (Danisco, Dangé-Saint-Romain, France) was stored at $-20^{\circ} \mathrm{C}$. It was thawed for $10 \mathrm{~min}$ at $37^{\circ} \mathrm{C}$ before inoculation, which was carried out at $3 \times 10^{6} \mathrm{cfu} / \mathrm{mL}$.
For starter production, the culture medium was composed of $56.4 \mathrm{~g} / \mathrm{L}$ of mild whey (BBA, Bonneuil-surMarne, France) that was heated to $110^{\circ} \mathrm{C}$ for $10 \mathrm{~min}$. After centrifugation $\left(17,000 \times g, 20 \mathrm{~min}, 15^{\circ} \mathrm{C}\right)$ and filtration $(0.45 \mu \mathrm{m}), 20 \mathrm{~g} / \mathrm{L}$ of lactose (Prolabo, Paris, France) and $5 \mathrm{~g} / \mathrm{L}$ of yeast extract (Labosi, Oulchy-LeChâteau, France) were added to the supernatant. The medium was sterilized in the fermentor at $110^{\circ} \mathrm{C}$ for $20 \mathrm{~min}$.

For measuring acidification activity, the medium was composed of reconstituted dried skim milk (100 g/L; Elle \& Vire, Condé sur Vire, France). It was pasteurized for $20 \mathrm{~min}$ at $110^{\circ} \mathrm{C}$ in $150-\mathrm{mL}$ Erlenmeyer flasks.

\section{Fermentation}

Cultures were grown in a 2-L fermentor, at different temperatures and $\mathrm{pH}$, with an agitation speed of 200 rpm. The $\mathrm{pH}$ was controlled by adding a $2 \mathrm{M} \mathrm{NaOH}$ solution that was continuously weighed. Absorbance measurements at $480 \mathrm{~nm}$ were used to characterize bacterial growth.

Growth was stopped at the beginning of the stationary phase. This was defined as the time at which the $\mathrm{NaOH}$ consumption rate, calculated in real time as the first time derivative of the $\mathrm{NaOH}$ weight decrease, started to decline. The cell suspension was then cooled to $15^{\circ} \mathrm{C}$ in the fermentor.

\section{Concentration and Preservation}

Cells were harvested at $15^{\circ} \mathrm{C}$ and concentrated by centrifugation $\left(17,000 \times g, 30 \mathrm{~min}\right.$ at $\left.4^{\circ} \mathrm{C}\right)$. Concentrated cells were resuspended at $4^{\circ} \mathrm{C}$ in $3 \times$ their weight of supernatant. Aliquots of $1 \mathrm{~mL}$ of concentrated cells were frozen at $0.75^{\circ} \mathrm{C} / \mathrm{min}$ and stored at $-20^{\circ} \mathrm{C}$ for $3 \mathrm{mo}$. They were thawed at $37^{\circ} \mathrm{C}$ for $5 \mathrm{~min}$ before acidification activity measurements.

\section{Acidification Activity Measurement}

The Cinac system (Corrieu et al., 1988) was used to measure the acidification activity of the suspensions of Lb. acidophilus RD758. Acidification was measured at $37^{\circ} \mathrm{C}$ and triplicated. The $\mathrm{pH}$ of inoculated milk samples was continuously measured and the time necessary to reach pH 5.5 (tpH5.5; in min) was used to characterize the acidification activity of the bacterial suspensions. The higher the tpH5.5, the longer the latency phase, and thus the lower the acidification activity.

The acidification activity was measured before and after freezing, and during $90 \mathrm{~d}$ of frozen storage at $-20^{\circ} \mathrm{C}$. The loss in acidification activity as a function of storage time (ts; in d) was modeled according to linear regressions as proposed by Fonseca et al. (2000): 


$$
\mathrm{tpH} 5.5=\mathrm{tc}+\mathrm{dtf}+\mathrm{k} \times \mathrm{ts}
$$

The parameter tc (in min) represents the initial acidification activity, measured before freezing. The parameter dtf (in min) displays the difference between the acidification activities measured before and after freezing. It corresponds to the loss in acidification activity during the freezing step. The parameter $\mathbf{k}$ (in $\mathrm{min} / \mathrm{d}$ ) is the slope of the regression line and represents the rate of loss in acidification activity during frozen storage.

\section{Fatty Acid Analysis}

The membrane fatty acid composition of the bacteria was determined using gas chromatography as described by Rozes et al., (1993) and adapted by Béal et al. (2001). Concentrated cells were washed in $0.05 M$ Tris solution. Methylation and extraction were performed simultaneously at $4^{\circ} \mathrm{C}$ by adding $1.5 \mathrm{~mL}$ of sodium methoxide (1 $M$ in methanol) (Sigma Aldrich, Steinheim, Germany) and shaking for $1.5 \mathrm{~min}$. Fatty acid methyl esters were extracted with $1 \mathrm{~mL}$ of hexane. One milliliter of undecanoic acid methyl ester $(0.1 \mathrm{mg} / \mathrm{mL}$ in hexane) (Sigma Aldrich) was added as an internal standard for gasliquid chromatography. After decanting for $5 \mathrm{~min}$, the upper phase was removed and stored at $-80^{\circ} \mathrm{C}$ in an airtight glass bottle until analysis.

The analyses were performed on a gas chromatographer (HP 6890, Hewlett Packard, Avondale, PA) equipped with a mass selective detector (Agilent 5973, Hewlett Packard). A capillary column (BPX 70, $60 \mathrm{~m} \times$ $0.25 \mathrm{~mm}$, SGE, Victoria, Australia) was used. Helium was used as carrier gas $(1.2 \mathrm{~mL} / \mathrm{min})$, and the injection volume was $2 \mu \mathrm{L}$. Injection was done in splitless mode for $2 \mathrm{~min}$. The oven temperature was increased from 65 to $230^{\circ} \mathrm{C}$ at $5^{\circ} \mathrm{C} / \mathrm{min}$, and maintained for $10 \mathrm{~min}$ at $230^{\circ} \mathrm{C}$. Injection and detection temperatures were $230^{\circ} \mathrm{C}$.

Results were expressed as relative percentages of each fatty acid, which were calculated as the ratio of the surface area of the considered peak to the total area of all peaks. The ratio of unsaturated to saturated fatty acids (U/S) was determined. The cycC19:0 fatty acid was considered unsaturated. Analyses were made in triplicate.

\section{Identification of the Major Peaks}

The fatty acid methyl esters were first identified by comparing their retention times with those of known standards (Sigma Aldrich). Their identification was confirmed using the mass selective detector. The electron impact energy was set at $70 \mathrm{eV}$ and data were collected in the range of 30 to 400 atomic mass units.
The identities of the fatty acid methyl esters (carbon number, position of the double bounds, and existence of a cyclopropane) were confirmed by comparing their mass spectra with the data bank (NBS75K and WILEY 275.L, Hewlett Packard). The cis-trans isomery of the double bounds or the cyclopropane was not established by this method.

\section{Experimental Design and Statistical Analyses}

The fermentation conditions were designed around a reference point set at $37^{\circ} \mathrm{C}$ and $\mathrm{pH}$. The reference point was duplicated. The experimental design made it possible to determine the effects of the fermentation $\mathrm{pH}(4.5,5$, and 6$)$, during cultures at $37^{\circ} \mathrm{C}$ and of the fermentation temperature $\left(30,37\right.$, and $\left.42^{\circ} \mathrm{C}\right)$, during cultures at $\mathrm{pH}$. An additional fermentation was carried out at $30^{\circ} \mathrm{C}$ and $\mathrm{pH} 5$.

To relate the acidification activity variables to the fatty acid composition of $L b$. acidophilus, principal component analysis (Statbox) was performed for all the fermentation conditions studied. Three acidification variables (tc, dtf, and $\mathrm{k}$ ) and 6 composition variables (U/S ratio and C16:0, C18:0, C18:1, C18:2, and cycC19:0 relative concentrations) were considered.

\section{RESULTS AND DISCUSSION}

\section{Influence of Fermentation Temperature on the Cryotolerance of Lb. acidophilus RD758}

The effect of the fermentation temperature on the cryotolerance of $L b$. acidophilus RD758 was determined by measuring the acidification activity after fermentation and concentration, after freezing, and during frozen storage. The initial acidification activity (tc, in min), which represents the cellular activity before freezing, varied with the fermentation temperature (Figure 1A). The highest initial acidification activity (i.e., the lowest tc) was obtained at $37^{\circ} \mathrm{C}$. By considering the confidence intervals, no significant difference was observed when fermentations were performed at 30 or $42^{\circ} \mathrm{C}$. As a consequence, the initial acidification activity was directly related to the fermentation temperature, which was optimal for growth at $37^{\circ} \mathrm{C}$ (results not shown).

According to Fonseca et al. (2000), the difference (dtf, in $\min$ ) between the initial acidification activity and the acidification activity measured just after freezing at $-20^{\circ} \mathrm{C}$ represents the loss in acidification activity during freezing. From Figure 1A, dtf increased with fermentation temperature: at $30^{\circ} \mathrm{C}$, no loss in acidification activity was observed ( $\mathrm{dtf}=0 \mathrm{~min}$ ), whereas $\mathrm{dtf}$ rose to $168 \mathrm{~min}$ at $42^{\circ} \mathrm{C}$. This indicates that a low fermentation temperature dramatically improved the cellular resistance to freezing. 

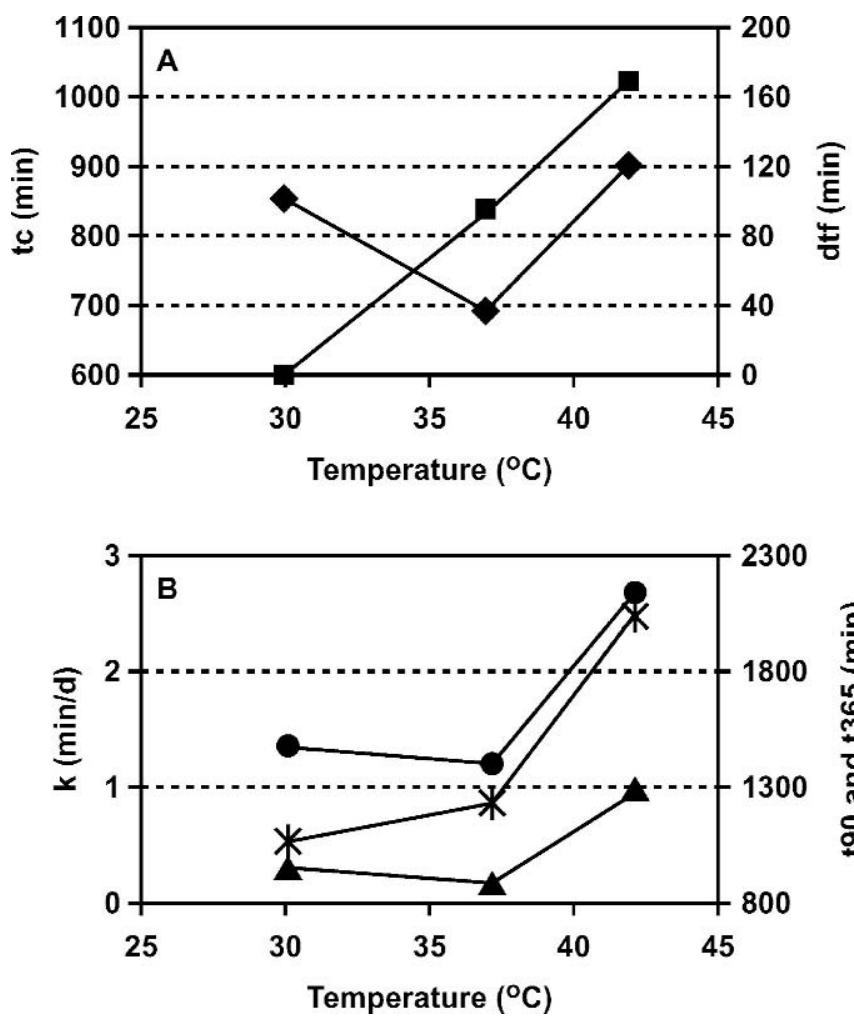

Figure 1. Effect of fermentation temperature on the acidification activity of Lactobacillus acidophilus RD758 at different steps of production. Fermentations were conducted at $\mathrm{pH} 6$; tc $(\bullet)=$ initial acidification activity measured before freezing $(\min ) ; \operatorname{dtf}(\boldsymbol{\square})=$ difference of acidification activity before and after freezing $(\mathrm{min}) ; \mathrm{k}(\bullet)=$ rate of loss in acidification activity during storage ( $\mathrm{min} / \mathrm{d}) ; \mathrm{t} 90(\mathbf{\Lambda})$ and t365 $(*)=$ residual acidification activity after 90 and $365 \mathrm{~d}$ of frozen storage (in $\mathrm{min}$ ).

During frozen storage, the acidification activity decreased linearly with storage time (Béal et al., 2001). This decrease was directly related to the loss in cellular viability (Figure 2). The rate of loss in the acidification activity of $L b$. acidophilus RD758 during frozen storage (k; in $\mathrm{min} / \mathrm{d}$ ) was between 1.2 and $2.7 \mathrm{~min} / \mathrm{d}$ (Figure 1B), depending on fermentation temperatures. The $\mathrm{k}$ values were similar at 30 and $37^{\circ} \mathrm{C}$, but increased significantly at $42^{\circ} \mathrm{C}$. This high fermentation temperature induced a more rapid decrease of the acidification activity, whereas, lower fermentation temperatures enabled better resistance of $L b$. acidophilus RD758 to frozen storage.

The residual acidification activity was measured after $3 \mathrm{mo}$ (t90) and calculated after $1 \mathrm{yr}$ (t365) of frozen storage at $-20^{\circ} \mathrm{C}$ (Figure $1 \mathrm{~B}$ ). These variables both displayed a higher acidification activity of the cells grown at 37 or $30^{\circ} \mathrm{C}$. These observations were related to the good initial acidification activity and to the excellent resistance during freezing after fermentation at these temperatures, respectively.

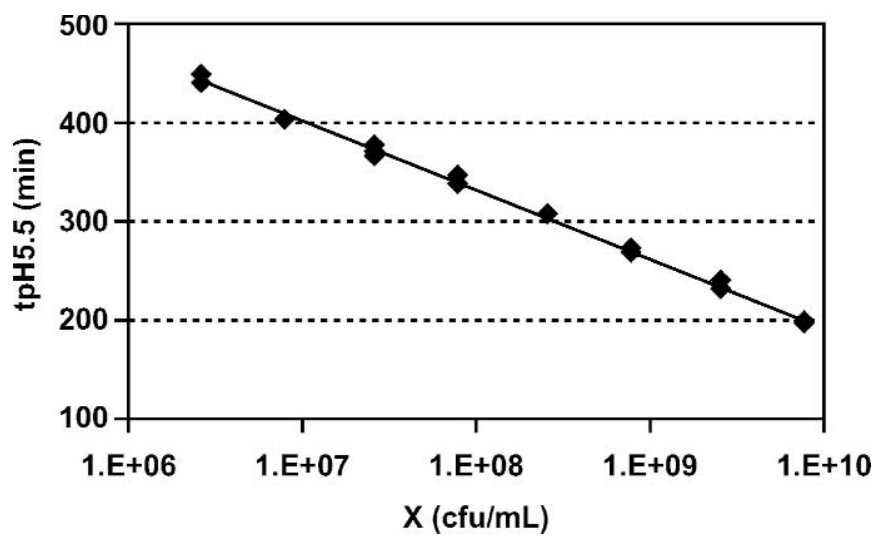

Figure 2. Linear relationship between the acidification activity (tpH5.5, in $\mathrm{min}$ ) and the microbial count $(\mathrm{X}$, in $\mathrm{cfu} / \mathrm{mL}$ ) enumerated on MRS agar incubated at $37^{\circ} \mathrm{C}$ for $48 \mathrm{~h}$; each value is the mean of 3 replicates. tpH5.5 $=878-29.7 \times \operatorname{Ln}(\mathrm{X})\left(\mathrm{R}^{2}=0.9964\right)$.

Finally, better cryoresistance of $L b$. acidophilus RD758 was observed when the cells were cultivated at a low fermentation temperature, between 30 and $37^{\circ} \mathrm{C}$. This is in agreement with previous studies, which showed an adaptation of $L b$. acidophilus to freezing when the culture was conducted at low temperature (Fernandez Murga et al., 2000). Nevertheless, these authors demonstrated that lower temperatures (22 or $25^{\circ} \mathrm{C}$ ) were necessary to induce cryoadaptation. The diversity of the strains used and the different fermentation conditions (noncontrolled $\mathrm{pH}$ ) may explain these different values.

\section{Influence of Fermentation pH on the Cryotolerance of Lb. acidophilus RD758}

Cultures of $L b$. acidophilus RD758 were conducted at 3 fermentation $\mathrm{pH}$ levels to demonstrate the effect of this factor on the initial acidification activity (tc, in $\min$ ), and on the cryoresistance of this strain. From Figure 3A, the cells grown at $\mathrm{pH} 6$ displayed the higher initial acidification activity, as tc was about $175 \mathrm{~min}$ lower than at other $\mathrm{pH}$ values. This indicates that the physiological state of cells grown in acidic conditions ( $\mathrm{pH} 4.5$ and 5) deteriorated more at the end of the culture than at $\mathrm{pH} 6$. This result may be related to the optimal $\mathrm{pH}$ value for growth, which was $\mathrm{pH} 6$ for $L b$. acidophilus (Taillandier et al., 1996).

The loss of acidification activity during freezing (dtf, in min) of cells grown at different $\mathrm{pH}$ is shown in Figure 3A. Cells grown at acidic $\mathrm{pH}$ ( $\mathrm{pH} 4.5$ and 5) did not lose their acidification activity during freezing $(\mathrm{dtf}=0 \mathrm{~min})$, unlike at $\mathrm{pH} 6$ (dtf = $90 \mathrm{~min})$. However, this loss of acidification activity observed at $\mathrm{pH} 6$ only partially counterbalanced the initial advantage observed with tc (175 min). 

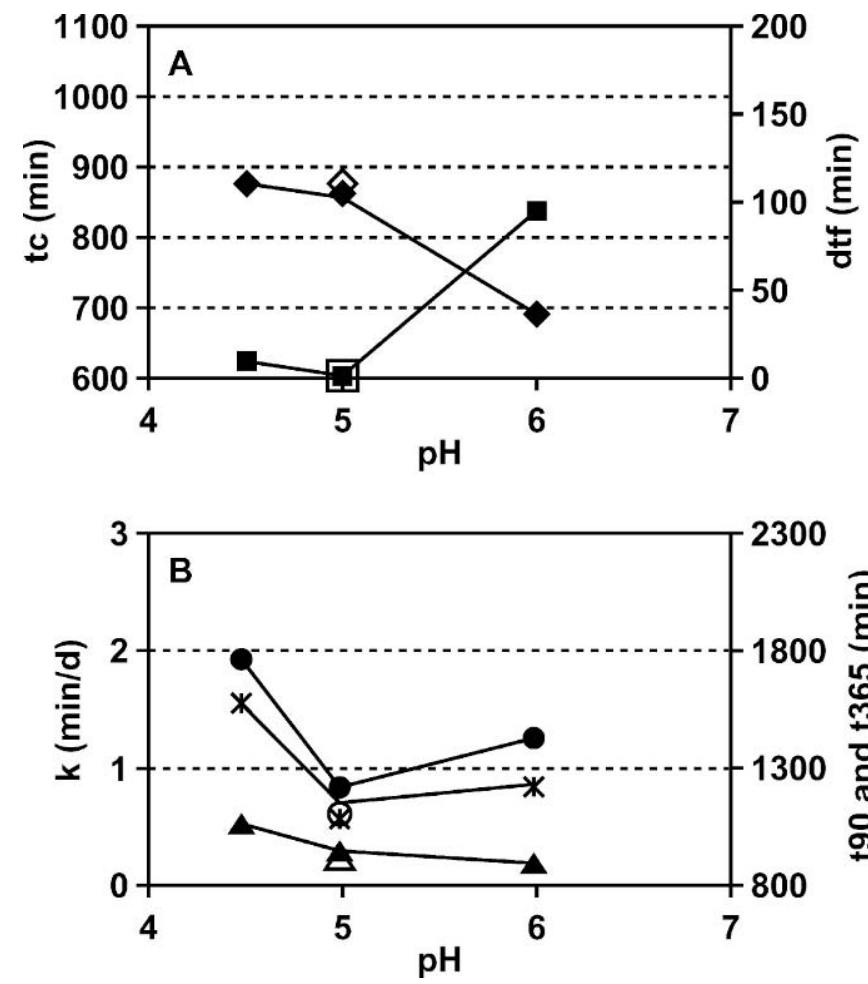

Figure 3. Effect of fermentation $\mathrm{pH}$ on the acidification activity of $L b$. acidophilus RD758 at different steps of its production. Fermentations were conducted at $37^{\circ} \mathrm{C}$ (closed symbols) or $30^{\circ} \mathrm{C}$ (open symbols); tc $(\bullet)=$ initial acidification activity measured before freezing (in $\min$ ); $\operatorname{dtf}(\boldsymbol{\square})=$ difference of acidification activity before and after freezing (in min); $\mathrm{k}(\mathbf{O})=$ rate of loss in acidification activity during storage $($ in $\mathrm{min} / \mathrm{d}) ; \mathrm{t} 90(\mathbf{\Lambda})$ and $\mathrm{t} 365(*)=$ residual acidification activity after 90 and 365 d of frozen storage (in min), respectively.

During frozen storage, the rates of loss of acidification activity ( $\mathrm{k}$, in $\mathrm{min} / \mathrm{d}$ ) were between 0.83 and $1.9 \mathrm{~min} /$ $\mathrm{d}$, depending on the fermentation $\mathrm{pH}$ (Figure 3B). They were higher at $\mathrm{pH} 4.5$, whereas no significant difference was observed between $\mathrm{pH} 5$ and 6 . This result indicates that very acidic conditions ( $\mathrm{pH} 4.5$ ) during fermentation were detrimental to bacterial resistance during frozen storage.

After 3 or $12 \mathrm{mo}$ of frozen storage at $-20^{\circ} \mathrm{C}$, the residual acidification activity was highest (t90 and t365 values were the lowest) at $\mathrm{pH}$ values between $\mathrm{pH} 5$ and 6 (Figure 3B). The good performance observed at $\mathrm{pH} 5$ was mainly due to the low loss in acidification activity during freezing and storage. For cells grown at $\mathrm{pH} 6$, the high initial acidification activity and relatively low rate of loss in acidification activity resulted in good residual activity. Finally, cells grown at $\mathrm{pH} 4.5$ displayed the worst residual acidification activity, indicating that there was no adaptation at this fermentation $\mathrm{pH}$ for Lb. acidophilus RD758. This suggests that a low $\mathrm{pH}$ limit exists, under which the adaptation of $L b$. acidophilus RD758 may not occur.
Our results are in agreement with previous works indicating that an acidic fermentation $\mathrm{pH}$ was better for the preservation of lactic acid bacteria: $\mathrm{pH} 5$ for $L b$. acidophilus (Gilliland and Rich, 1990) and Lactobacillus reuteri (Palmfeldt and Hahn Hagerdal, 2000), and pH 5.5 for Strep. thermophilus (Béal et al., 2001). Moreover, they pointed out that different events occurred with freezing or during frozen storage, thus leading to different bacterial resistance.

To combine the good cryotolerances observed at acidic $\mathrm{pH}$ and low temperature, an additional fermentation was conducted at $\mathrm{pH} 5$ and $30^{\circ} \mathrm{C}$. The initial acidification activity (tc) and the loss in acidification activity during freezing (dtf) were equivalent to those observed after fermentation at $\mathrm{pH} 6$ and $37^{\circ} \mathrm{C}$ (Figure 3A). However, the cells displayed a lower rate of loss in acidification activity during frozen storage $(\mathrm{k}=0.6 \mathrm{~min} / \mathrm{d})$ and better residual acidification activity after $12 \mathrm{mo}$ of storage (Figure 3B). This demonstrates that combining a low fermentation $\mathrm{pH}(\mathrm{pH} 5)$ and a low fermentation temperature $\left(30^{\circ} \mathrm{C}\right)$ was a good way to improve the cryotolerance of $L b$. acidophilus RD758 during frozen storage.

\section{Cellular Fatty Acid Composition of Lb. acidophilus RD758}

To understand the physiological modifications induced by the previously observed responses, the membrane fatty acid composition of $L b$. acidophilus RD758 was characterized. Thirteen fatty acids were observed in the membrane of $L b$. acidophilus RD758 cultivated at $\mathrm{pH} 6$ and $37^{\circ} \mathrm{C}$. The 7 main peaks were identified as tetradecanoic (myristic) acid (C14:0), pentadecanoic acid (C15:0), hexadecanoic (palmitic) acid (C16:0), octadecanoic (stearic) acid (C18:0), octadecenoic (oleic or vaccenic) acids (C18:1), octadecadienoic (linoleic) acid (C18:2), and methylenoctadecenoic (dihydrosterculic or lactobacillic) acids (cycC19:0). Their relative percentages were between 1 and $48 \%$, corresponding to more than $90 \%$ of all fatty acids. Six minor fatty acids were also detected, at lower relative concentrations: decanoic acid (C10:0), dodecanoic acid (C12:0), tridecanoic acid (C13:0), hexadecenoic (palmitoleic) acid (C16:1), heptadecanoic acid (C17:0), and methylenhexadecanoic acid (cycC17:0). All these fatty acids, encountered in the membrane of $L b$. acidophilus RD758, have been identified previously in Lb. acidophilus (Brennan et al., 1986; Fernandez Murga et al., 2000).

The ratio between unsaturated and saturated fatty acids was equal to 0.23 for the cells grown at $37^{\circ} \mathrm{C}$ and $\mathrm{pH}$ 6. It was low compared with the values obtained by Fernandez Murga et al. (1999) (2.88) and Gomez Zavaglia et al. (2000) (0.86) with Lb. acidophilus. This 


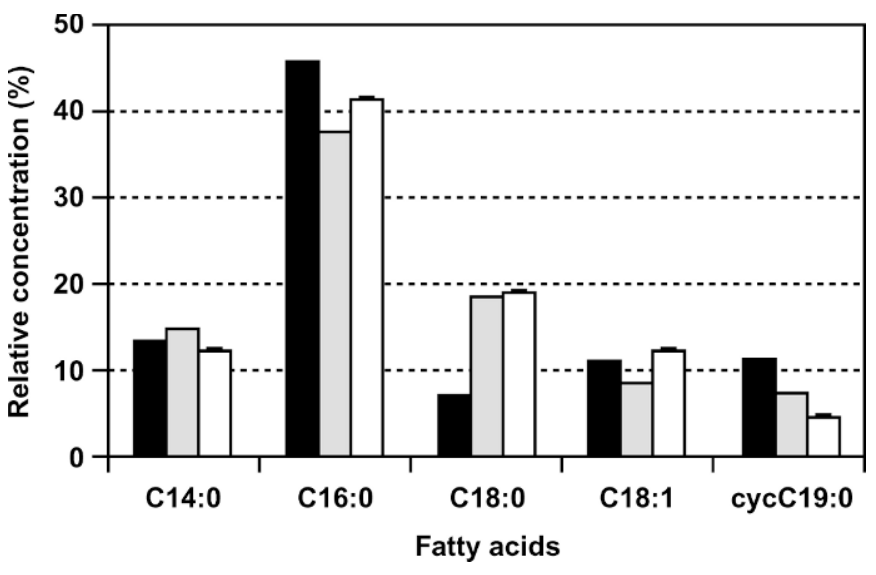

Figure 4. Influence of fermentation temperature on the membrane fatty acid composition of $L b$. acidophilus RD758. Fermentations were conducted at $\mathrm{pH} 6$ and at $30(\square), 37(\square)$, and $42^{\circ} \mathrm{C}(\square)$.

may be explained by the different conditions used by these authors, and mainly by the presence of Tween 80 in the media used in the 2 earlier studies.

\section{Influence of Fermentation Temperature on Membrane Fatty Acid Composition of Lb. acidophilus RD758}

The fermentation temperature influenced the concentration of the main membrane fatty acids of $L b$. acidophilus RD758. The highest U/S ratio (0.34) was found in cells grown at the lowest temperature $\left(30^{\circ} \mathrm{C}\right)$, whereas values between 0.23 and 0.24 were observed at 37 and $42^{\circ} \mathrm{C}$. When considering the confidence intervals $( \pm 0.12)$, there was no significant difference between these 2 temperatures. Consequently, a membrane adaptation of Lb. acidophilus RD758, corresponding to an increase in the U/S ratio, was observed at low fermentation temperature. This result was in agreement with those of Lonvaud-Funel and Desens (1990) with $L b$. plantarum, Suutari and Laakso (1992) with Lb. fermentum, and Fernandez Murga et al. (2000) with $L b$. acidophilus.

The changes in the relative percentages of 5 predominant fatty acids (C14:0, C16:0, C18:0, C18:1, and cycC19:0), measured after fermentations at different temperatures, are shown in Figure 4. The fermentation temperatures did not significantly affect the C14:0, $\mathrm{C} 15: 0$, and $\mathrm{C} 18: 2$ relative concentrations that were 13 , 13 , and $2 \%$, respectively. This result differed from that of Suutari and Laakso (1992), obtained with Lb. fermentum, probably because of the different bacterial species tested. The C16:0 and C18:1 fatty acids demonstrated similar distribution, with a low value at $37^{\circ} \mathrm{C}$, as compared with 30 and $42^{\circ} \mathrm{C}$. They both influenced the U/S ratio in the same way. This result partially agreed with those reported in the literature: the C16:0 concentration in $L b$. acidophilus (Fernandez Murga et al., 2000) and the C18:1 concentration in Lb. plantarum (Russell et al., 1995) increased in response to low culture temperatures. The relative percentage of the C18:0 fatty acid was low $(7 \%)$ at $30^{\circ} \mathrm{C}$ but increased significantly at higher temperatures (19\%). This large difference (12\%) greatly influenced the U/S ratio. A low C18:0 concentration in $L b$. acidophilus grown at $30^{\circ} \mathrm{C}$ was found by Fernandez Murga et al. (2000), even though they also obtained a low value at $37^{\circ} \mathrm{C}$. Finally, a high relative concentration of the cycC19:0 fatty acid was observed at $30^{\circ} \mathrm{C}$. This result was in agreement with that of Suutari and Laakso (1992) but differed from that of Fernandez Murga et al. (1999). These differences may be related to the different strains and culture media used.

Finally, our results showed that a low fermentation temperature induced membrane adaptations in $L b$. acidophilus RD758. It was related to high $\mathrm{C} 16: 0$ and cycC19:0 relative concentrations, to a low C18:0 content and to a high U/S ratio.

\section{Influence of Fermentation pH on Membrane Fatty Acid Composition of Lb. acidophilus RD758}

The U/S ratios of $L b$. acidophilus RD758 membranes grown at different fermentation $\mathrm{pH}$ were calculated. They were higher for the cells grown at acidic $\mathrm{pH}(0.30$ to 0.35$)$ compared with the cells grown at $\mathrm{pH} 6(0.23)$. This phenomenon has been observed in $L b$. reuteri (Palmfeldt and Hahn Hagerdal, 2000), Oenococcus oeni (Bastianini et al., 2000), and Strep. thermophilus (Béal et al., 2001). The lowest U/S ratio, found in the cells grown at $\mathrm{pH} 6$, can be related to the lowest acid stress under these conditions.

The relative concentrations of 5 fatty acids (C14:0, C16:0, C18:0, C18:1, and cycC19:0) were influenced by the fermentation $\mathrm{pH}$. According to Figure 5, the changes in the relative concentrations of $\mathrm{C} 16: 0, \mathrm{C} 18: 0$, and cycC19:0 fatty acids were large (4.5 to $10 \%)$, whereas the variations of $\mathrm{C} 14: 0$ and $\mathrm{C} 18: 1$ were low (2.5\%). The relative concentrations of $\mathrm{C} 15: 0$ and $\mathrm{C} 18: 2$ were not affected by fermentation $\mathrm{pH}$. A high $\mathrm{C} 16: 0$ concentration was observed at acidic $\mathrm{pH}$ (45\%) compared with $\mathrm{pH}$ $6(38 \%)$. This was not consistent with previous studies. According to Drici-Cachon et al. (1996) with Oe. oeni, and Béal et al. (2001) with Strep. thermophilus, the relative $\mathrm{C} 16: 0$ concentration was low at $\mathrm{pH} 2.9$ and 5.5, respectively. This difference may be related to the use of different bacterial species by these authors. The cycC19:0 concentration increased when lowering the fermentation $\mathrm{pH}$. It was high $(12 \%)$ at $\mathrm{pH} 4.5$ and 5 , 


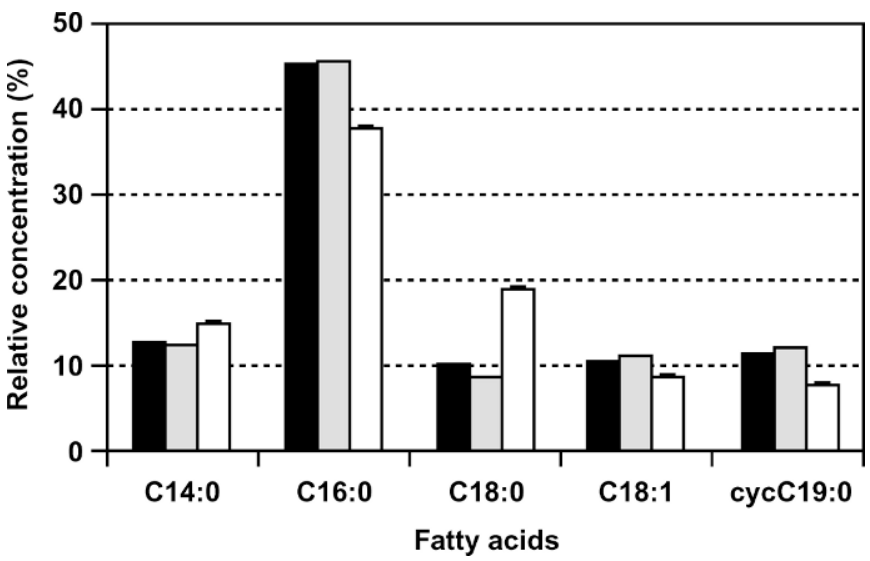

Figure 5. Influence of fermentation $\mathrm{pH}$ on the membrane fatty acid composition of Lactobacillus acidophilus RD758. The fermentations were conducted at $37^{\circ} \mathrm{C}$ and at $\mathrm{pH} 4.5(\square), \mathrm{pH} 5(\square)$, and $\mathrm{pH} 6$ (口).

instead of $6 \%$ at $\mathrm{pH} 6$. This result is in agreement with previous studies (Drici-Cachon et al., 1996; Bastianini et al., 2000; Béal et al., 2001). Unlike the C16:0 and cycC19:0 fatty acids, the C18:0 relative content was lower at acidic $\mathrm{pH}$, as already shown in Strep. thermophilus (Béal et al., 2001). This highly affected the U/S ratio because of the large difference observed (10\%).

Consequently, a membrane adaptation of $L b$. acidophilus RD758 was observed at low fermentation $\mathrm{pH}$, as shown by an increase in the U/S ratio and in the C16:0 and cycC19:0 relative concentrations, and by a decrease in the C18:0 relative concentration. This adaptation was similar to that observed previously at low fermentation temperature.

\section{Relationship Between the Membrane Fatty Acid Composition and the Cryotolerance of $L b$. acidophilus RD758 Grown at Different pH and Temperatures}

Our results showed some relation between the cryotolerance and the membrane fatty acid composition of $L b$. acidophilus RD758, cultivated at different fermentation $\mathrm{pH}$ and temperatures. As a consequence, a principal component analysis was performed to evaluate these relationships, for the whole range of culture conditions (Figure 6A).

The first 2 dimensions accounted for $83 \%$ of the data variance. The fermentation conditions were discriminated along the first axis according to the C18:0, C16:0, and cycC19:0 relative concentrations, the U/S ratio, and the loss of acidification activity during freezing (dtf). Principal component 2 was determined by the rate of loss in acidification activity during frozen storage at $-20^{\circ} \mathrm{C}(\mathrm{k})$ and, to a lesser extent, by the initial acidifica-
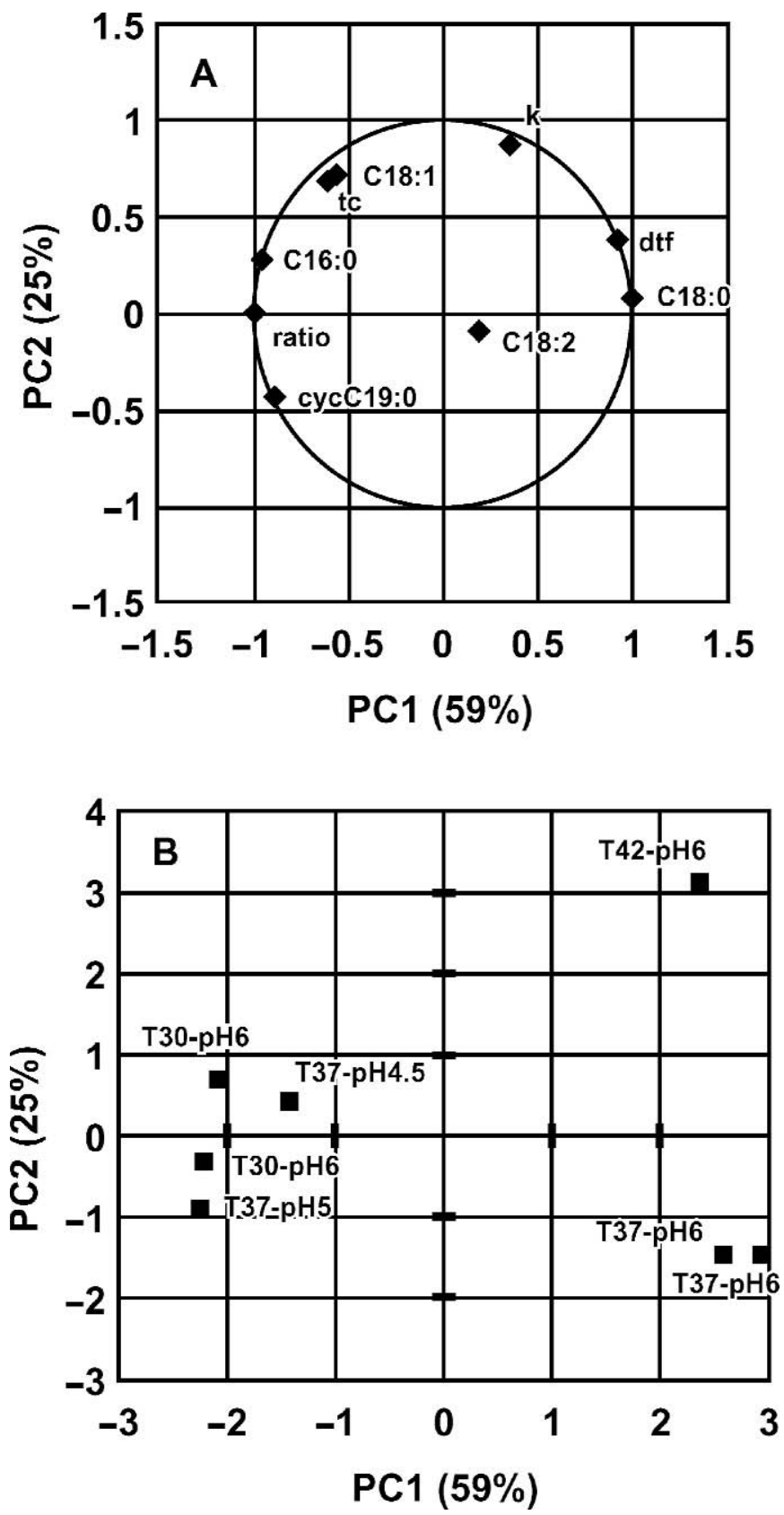

Figure 6. Principal component analysis of the 3 acidification variables (tc, dtf, and $\mathrm{k}$ ) and the 6 fatty acid composition variables (unsaturated/saturated ratio, $\mathrm{C} 16: 0, \mathrm{C} 18: 0, \mathrm{C} 18: 1, \mathrm{C} 18: 2$, and cycC19:0 relative concentrations) (A), showing the distribution of the samples obtained after fermentations at different $\mathrm{pH}$ and temperatures $(\mathrm{B}) . \mathrm{tc}=$ Initial acidification activity measured before freezing; $\mathrm{dtf}=$ difference in acidification activity before and after freezing; $\mathrm{k}=$ rate of loss in acidification activity during storage.

tion activity (tc) and the C18:1 content. The third axis accounted for an additional variance of $13 \%$ and was controlled by the $\mathrm{C} 18: 2$ relative concentration.

High correlations were observed between C18:0, $\mathrm{C} 16: 0$, and cycC19:0 concentrations and the U/S ratio, 
thus confirming the conclusions previously obtained. Moreover, the variable associated with the freezing step (dtf) exhibited a good correlation with these variables: a high tolerance to the freezing step, i.e., a low dtf, was associated with a high U/S ratio $(\mathrm{R}=-0.874)$, a low C18:0 content $(R=0.934)$, and high $C 16: 0(R=-0.77)$, and cycC19:0 $(\mathrm{R}=-0.96)$ relative concentrations. The rate of loss in acidification activity during frozen storage $(\mathrm{k})$ was inversely correlated to the cyc $\mathrm{C} 19: 0$ relative concentration $(\mathrm{R}=-0.725)$ : a high cycC19:0 induced a low $\mathrm{k}$ value and a high resistance during storage. Finally, the initial acidification activity correlated well with $\mathrm{C} 18: 1(\mathrm{R}=0.752)$ and $\mathrm{C} 16: 0(\mathrm{R}=0.72)$ concentrations.

Clustering was obtained according to the fermentation conditions (Figure 6B). The 2 fermentations conducted at $\mathrm{pH} 6$ and $37^{\circ} \mathrm{C}$ are grouped in the lower right quadrant. They showed a high value of $\mathrm{dtf}$, but low tc and $\mathrm{k}$ values, associated with high $\mathrm{C} 18: 0$ and cycC19:0 relative concentrations, high U/S ratio, and low $\mathrm{C} 16: 0$ and C18:1 relative concentrations. The fermentation performed at $\mathrm{pH} 6$ and $42^{\circ} \mathrm{C}$ is situated in the upper right quadrant. It is characterized by high C18:0 and C18:1 contents and low cyc C19:0 concentration, and by high values of $\mathrm{dtf}$ and $\mathrm{k}$, thus indicating very poor cryotolerance. The fermentations conducted at low temperature $\left(\mathrm{pH} 6\right.$ and $\left.30^{\circ} \mathrm{C}\right)$ or at low $\mathrm{pH}\left(37^{\circ} \mathrm{C}\right.$ and $\mathrm{pH}$ 5 or 4.5) are grouped in the negative half of the first axis. They were distinguished by their high $\mathrm{C} 16: 0$ and cycC19:0 relative concentrations and U/S ratio, and their low C18:0 relative concentration. These characteristics were associated with a low $\mathrm{dtf}$ value, i.e., a good resistance to the freezing step, which was counteracted by a high tc value. Finally, the third axis made it possible to differentiate the fermentation performed at $\mathrm{pH}$ 4.5 , which was characterized by a low C18:2 concentration and a relatively high $\mathrm{k}$ value.

From these results, strong relationships were observed between the resistance of $L b$. acidophilus $\mathrm{RD} 758$ to the freezing step and the relative contents of $\mathrm{C} 16: 0$, C18:0, and cycC19:0 fatty acids on the one hand, and between the resistance during the frozen storage and the cycC19:0 relative concentrations, on the other hand. Moreover, the poor cryotolerance observed at $\mathrm{pH} 4.5$ was associated with a decreased content in C18:2 fatty acid. Therefore, good control of the concentration of these 4 key fatty acids may improve the cryotolerance of $L b$. acidophilus RD758. Such control was obtained by applying specific fermentation conditions (low fermentation temperature and $\mathrm{pH}$ ). This was confirmed by the fermentation conducted at $\mathrm{pH} 5$ and $30^{\circ} \mathrm{C}$, which showed high tolerance to the freezing step ( $\mathrm{dtf}=0 \mathrm{~min}$ ) and to frozen storage $(\mathrm{k}=0.6 \mathrm{~min} / \mathrm{d})$, and displayed high contents in $\mathrm{C} 16: 0$ and cycC19:0 fatty acids and a low C18:0 concentration.

\section{CONCLUSIONS}

The fermentation $\mathrm{pH}$ and temperature influenced the resistance to freezing and frozen storage of $L b$. acidophilus RD758. The best initial acidification activity was obtained when the cells were cultivated at $37^{\circ} \mathrm{C}$ and $\mathrm{pH} 6$, which corresponded to the optimal temperature and $\mathrm{pH}$ for growth. The loss in acidification activity during freezing and frozen storage increased with fermentation temperature and $\mathrm{pH}$. The best tolerance was observed at $30^{\circ} \mathrm{C}$ or at $\mathrm{pH} 5$. The increased resistance to freezing was linked to low C18:0 content, and to high $\mathrm{C} 16: 0$ and cycC19:0 relative concentrations. The best resistance to frozen storage was explained by a high cycC19:0 content. Finally, a fermentation $\mathrm{pH}$ of 4.5 was detrimental to cryotolerance, which was related to the C18:2 content.

These results need to be complemented by an analysis of the proteomic responses of cells to different culture conditions in relation to their cryotolerance. This analysis may point out the increased synthesis of some stress proteins (Wouters et al., 1999; Lorca and Font de Valdez, 2001) and, particularly, of some enzymes involved in the synthesis of these specific fatty acids, such as desaturases.

\section{ACKNOWLEDGMENTS}

The authors thank Danisco for kindly providing the Lb. acidophilus RD758 strain.

\section{REFERENCES}

Aubert, C., N. Capelle, S. Jeanson, H. Eckert, C. Divies, and R. Cachon. 2002. Le potentiel d'oxydoréduction et sa prise en compte dans les procédés d'utilisation des bactéries lactiques. Sci. Aliments 22:177-187.

Bastianini, A., S. Granchi, S. Guerrini, and M. Vincenzini. 2000. Fatty acid composition of malolactic Oenococcus oeni strains exposed to pH and ethanol stress. Ital. J. Food Sci. 12:333-342.

Béal, C., F. Fonseca, and G. Corrieu. 2001. Resistance to freezing and frozen storage of Streptococcus thermophilus is related to membrane fatty acid composition. J. Dairy Res. 84:2347-2356.

Brennan, M., B. Wanismail, M. C. Johnson, and B. Ray. 1986. Cellular damage in dried Lactobacillus acidophilus. J. Food Prot. 49:47-53.

Broadbent, J. R., C. J. Oberg, H. Wang, and L. Wei. 1997. Attributes of the heat shock response in three species of dairy Lactobacillus. Syst. Appl. Microbiol. 20:12-19.

Corrieu, G., H. E. Spinnler, Y. Jomier, and D. Picque. 1988. Procédé de mise en évidence et de contrôle de l'activité acidifiante d'agents de fermentation dans des bains de fermentation et dispositif pour sa mise en æuvre. INRA, French Patent 8804456.

De Angelis, M., L. Bini, V. Pallini, P. S. Cocconcelli, and M. Gobbetti. 2001. The acid-stress response in Lactobacillus sanfranciscensis CB1. Microbiology 147:1863-1873.

Desmond, C., C. Stanton, G. F. Fitzgerald, K. Collins, and R. Ross. 2002. Environmental adaptation of probiotic lactobacilli towards 
improvement of performance during spray drying. Int. Dairy J. 12:183-190.

Drici-Cachon, Z., J. F. Cavin, and C. Diviès. 1996. Effect of $\mathrm{pH}$ and age of culture on cellular fatty acid composition of Leuconostoc oenos. Lett. Appl. Microbiol. 22:331-334.

Fernandez Murga, M. L., D. Bernik, G. Font de Valdez, and A. E. Disalvo. 1999. Permeability and stability properties of membranes formed by lipids extracted from Lactobacillus acidophilus grown at different temperatures. Arch. Biochem. Biophys. 364:115-121.

Fernandez Murga, M. L., G. M. Cabrera, G. Font De Valdez, A. Disalvo, and A. M. Seldes. 2000. Influence of growth temperature on cryotolerance and lipid composition of Lactobacillus acidophilus. J. Appl. Microbiol. 88:342-348.

Fonseca, F., C. Béal, and G. Corrieu. 2000. Method of quantifying the loss of acidification activity of lactic acid starters during freezing and frozen storage. J. Dairy Res. 67:83-90.

Fonseca, F., C. Béal, F. Mihoub, M. Marin, and G. Corrieu. 2003. Improvement of cryopreservation of Lactobacillus delbrueckii subsp. bulgaricus CFL1 with additives displaying different protective effects. Int. Dairy J. 13:917-926.

Foschino, R., E. Fiori, and A. Galli. 1996. Survival and residual activity of Lactobacillus acidophilus frozen cultures under different conditions. J. Dairy Res. 63:295-303.

Frees, D., F. K. Vogensen, and H. Ingmer. 2003. Identification of proteins induced at low $\mathrm{pH}$ in Lactococcus lactis. Int. J. Food Microbiol. 87:1-8.

Gilliland, S. E., and C. N. Rich. 1990. Stability during frozen and subsequent refrigerated storage of Lactobacillus acidophilus grown at different pH. J. Dairy Sci. 73:1187-1192.

Gilliland, S. E., and M. L. Speck. 1974. Relationship of cellular components to the stability of concentrated lactic Streptococcus cultures at $-17^{\circ} \mathrm{C}$. Appl. Microbiol. 27:793-796.

Gomez Zavaglia, A., A. E. Disalvo, and L. G. De Antoni. 2000. Fatty acid composition and freeze-thaw resistance in Lactobacilli. J. Dairy Res. 67:241-247.

Guerzoni, M. E., R. Lanciotti, and P. S. Cocconcelli. 2001. Alteration in cellular fatty acid composition as a response to salt, acid, oxidative and thermal stresses in Lactobacillus helveticus. Microbiology 147:2255-2264.

Guillot, A., D. Obis, and M. Y. Mistou. 2000. Fatty acid membrane composition and activation of glycine-betaine transport in Lactococcus lactis subjected to osmotic stress. Int. J. Food Microbiol. $55: 47-51$.
Lim, E. M., S. D. Ehrlich, and E. Maguin. 2000. Identification of stress-inducible proteins in Lactobacillus delbrueckii subsp. bulgaricus. Electrophoresis 21:2557-2561.

Lonvaud-Funel, A., and C. Desens. 1990. Constitution en acides gras des membranes des bactéries lactiques du vin. Incidences des conditions de culture. Sci. Aliments 10:817-829.

Lorca, G. L., and G. Font de Valdez. 2001. A low-pH-inducible, stationary-phase acid tolerance response in Lactobacillus acidophilus CRL 639. Curr. Microbiol. 42:21-25.

Maus, J. E., and S. C. Ingham. 2003. Employment of stressful conditions during culture production to enhance subsequent cold- and acid-tolerance of bifidobacteria. J. Appl. Microbiol. 95:146-154.

Monnet, C., C. Béal, and G. Corrieu. 2003. Improvement of the resistance of Lactobacillus delbrueckii ssp. bulgaricus to freezing by natural selection. J. Dairy Sci. 86:3048-3053.

Palmfeldt, J., and B. Hahn Hagerdal. 2000. Influence of culture $\mathrm{pH}$ on survival of Lactobacillus reuteri subjected to freeze-drying. Int. J. Food Microbiol. 55:235-238.

Rozes, N., S. Garbay, M. Denayrolles, and A. Lonvaud-Funel. 1993. A rapid method for the determination of bacterial fatty acid composition. Lett. Appl. Microbiol. 17:126-131.

Russell, N. J., R. I. Evans, P. F. Ter Steeg, J. Hellemons, A. Verheul, and T. Abee. 1995. Membranes as a target for stress adaptation. Int. J. Food Microbiol. 28:255-261.

Suutari, M., and S. Laakso. 1992. Temperature adaptation in Lactobacillus fermentum: Interconversions of oleic, vaccenic and dihydrosterculic acids. J. Gen. Microbiol. 138:445-450.

Taillandier, P., F. Gilis, F. Ramon Portugal, P. Laforce, and P. Stréhaiano. 1996. Influence of medium composition, $\mathrm{pH}$ and temperature on the growth and viability of Lactobacillus acidophilus. Biotechnol. Lett. 18:775-780.

Teixeira, H., M. G. Goncalves, N. Rozes, A. Ramos, and M. V. San Romao. 2002. Lactobacillic acid accumulation in the plasma membrane of Oenococcus oeni: A response to ethanol stress? Microb. Ecol. 43:146-153.

To, C. S. B., and M. R. Etzel. 1997. Spray drying, freeze-drying, or freezing of three different lactic acid bacteria species. J. Food Sci. 62:576-578, 585 .

Wouters, J. A., H. Frenkiel, W. M. de Vos, O. P. Kuipers, and T. Abee. 2001. Cold shock proteins of Lactococcus lactis MG1363 are involved in cryoprotection and in the production of cold-induced proteins. Appl. Environ. Microbiol. 67:5171-5178.

Wouters, J. A., F. M. Rombouts, W. M. De Vos, O. P. Kuipers, and T. Abee. 1999. Cold shock proteins and low-temperature response of Streptococcus thermophilus CNRZ302. Appl. Environ. Microbiol. 65:4436-4442. 